\title{
Inequality in the Ivory Tower: Sub-Representation of Arab Citizensin Israeli Universities
}

\author{
Nohad A'li \\ Western Galilee Academic College, Akko, Israel
}

\begin{abstract}
Research on minority representation in academia has not receive serious scholarly attention until recently, apparently due to the belief that academia is a paragon of liberalism, openness and equal opportunity, however, the few studies that were conducted have completely contradicted this assumption. This paper deals with the representation of Arab citizens in Israel's academia, universities in particular. The Study ${ }^{1}$ explores the representation/sub-representation of Arabcitizens in three main areas: The percentage of Arab students (from the BA to the Doctoral level); representation in faculties; and representation on permanent administrative staff. The paper offers up-to-date and precise data, which we received from the academic institutions themselves, and tries to lay the infrastructure for a broader and more in-depth study, which will deal with the barriers facing Arab citizens in Israeli universities.
\end{abstract}

Keywords: Higher education, academic institutions, Arab minority, fair representation, discrimination, barriers, faculties

\section{Introduction}

Higher education serves an important role in modern society. Higher education at its best is the only institution in modern society that has the potential to address most challenges confronting humanity (Pullias, 1964).

In Israel, a deeply divided society, one of the only issues on which all Israeli society agrees is the importance of access to education for the entire population. The higher education system is virtually the only place in which all parts of Israeli society take part, and in which the future social elites are molded (A'li, 2013).

The following quantitative study deals with the representation of Arab citizens in Israel's eight universities (Technion-Israel Institute of Technology, the University of Haifa, Ben-Gurion University of the Negev, Tel-Aviv University, Bar-Ilan University, The Hebrew University of Jerusalem, the Open University, and the Weizmann Institute of Science), in three main areas: the percentage of Arab students (from the BA to the Doctoral level); representation on the faculty (from the position of lecturer and above); and representation on the permanent administrative staff (not included is the category of "contract worker").

Minority representation in institutions of higher learning is of great importance. Higher education plays a central role in one's future ability to earn a living and in social and economic mobility. Moreover, minority

\footnotetext{
Nohad A’li, Ph.D., Senior Lecturer, Department of Sociology, Western Galilee Academic College.

${ }^{1}$ We owe special thanks to Sikkuy and the Pears foundations for their generous support which enabled us to conduct this research.
} 
participation in processes of decision-making in public institutions, certainly, when it comes to academic institutions, which are supposed to be accessible and open to all and to foster free discussion, is of great importance.

Under a democratic regime people, who acquire higher education expect equal opportunities, such as the right to equal opportunity in employment, including, of course, in the higher education system (Awad, 2008; A'li, 2011).

Higher education among the Arab minority is a tool both for social mobility and for social and political change (Meri, 1985, 1986). The Shochat Committee Report on reforms in the higher education system (2006) noted that the successful integration of Arab citizens in the universities is crucial for Israeli society and the Israeli economy in order to promote modernization, economic growth and equality. However, there are large disparities among various communities and groups, as a direct result of the class structure, in which those of European and American origin are still at the top, those of Asian and African origin in the middle, and the Arabs on the bottom. Members of different groups therefore have different starting points, which perpetuate the economic, social, class, ethnic and national inequality (Shafferman, 2007).

Higher education significantly promotes the Arabs' chances of integration into the job market, and studies have shown that while its acquisition empowers the Arab minority and can end its marginalization, Arabs continue to suffer discrimination in the job market. This means that education still does not lead to complete equal opportunities (Mustafa, 2007). This should not lead us to conclude that higher education is futile; rather, it should promote the removal of barriers in order to lead to mobility, excellence and representation.

The present study offers up-to-date and precise data, which we received as from the academic institutions themselves, and tries to lay the infrastructure for a broader and more in-depth study, which will deal with the barriers preventing fair representation of Arab citizens in Israeli universities.

\section{Minorities and Higher Education}

For minority groups in a multinational and multicultural societies education is of special importance. The education system can be a factor aiding development and advancement or a factor, which fosters social stagnation. In the modern state, university and higher education have always been perceived as a means of promoting the professional and social status of minority groups (Abu-Asba, 1997, 2005; David, 2007; McCluskey, 2015). One reason why governments invest in education is that they see it as a tool for shaping society. Governments' interest in it increase with the spread of the belief that education has a decisive influence on social inequality and that the social role of the individual is affected by the education she/he receives (Jewsona, Masona, Bowen, Mulvaney, \& Parmar, 1991). As a result of globalization, migration, modernization etc., over 90 percent of the countries in the world are heterogeneous in terms of their citizens' ethnic origin, nationality and culture.

At the start of the millennium there are minority groups living in most countries in the world, with a sizeable minority in many of them. Research on minority representation in academia has not receive serious scholarly attention until recently, apparently due to the belief that academia is a paragon of liberalism, openness and equal opportunity However, the few studies that were conducted, have completely contradicted this assumption. According to Jewsona et al. (1991), a prevailing assumption is that traditional academic ethics do not recognize barriers to acceptance into academia other than talent and ability, and therefore concepts such as equal opportunity for members of various ethnic groups were perceived as irrelevant. 


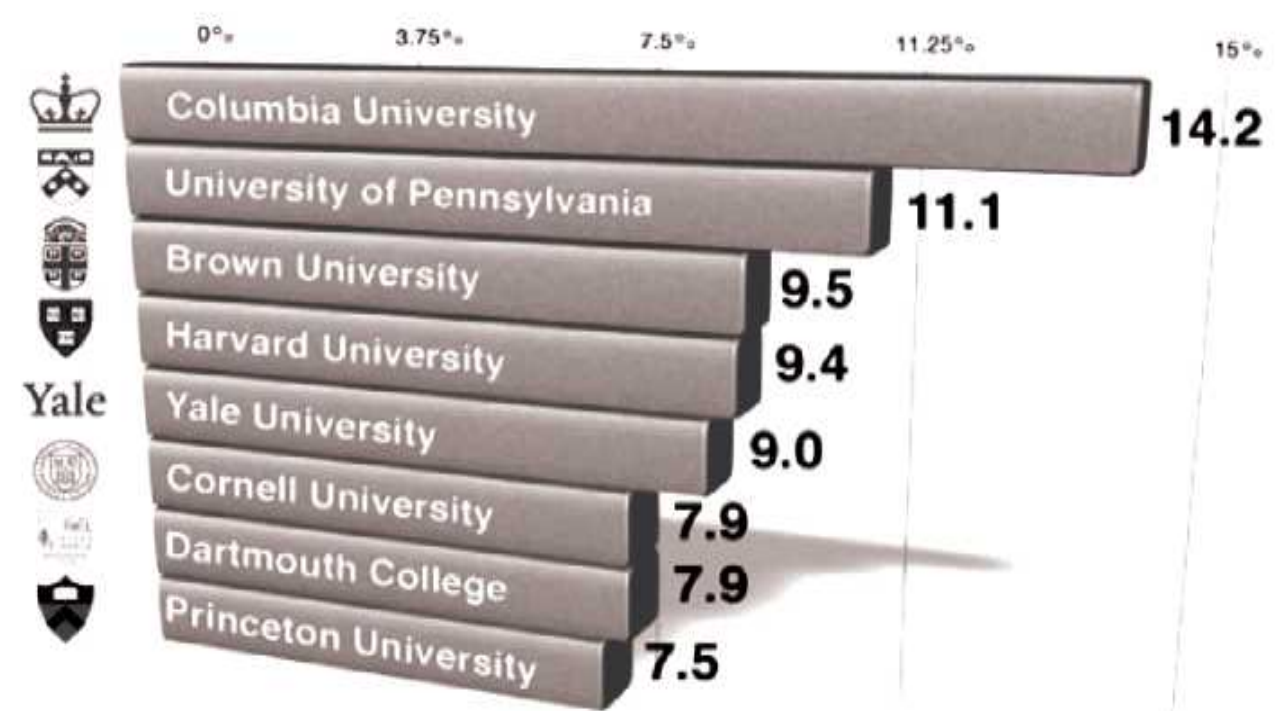

Figure 1. Percentage of African-American students in the freshmanclass in the eight Ivy League academic institutions, 2012.

In a speech given by Andrew Pilkington (Cited in Leathwood, Uvanney, \& Marie-Pierre, 2009) at the annual conference of the British Sociological Association, he claimed that efforts to promote equality in higher education have waned in the past decade, because the efforts that were made had little effect. The government pays only lip service, the universities do not treat the subject seriously when they hire faculty members, and even the discourse about racial equality and ethnic diversity has become marginal in England. In light of all this, it is not surprising to discover that members of ethnic minorities suffer from under-representation in higher education.

In his book, Pilkington (2011) discusses the disdain for racial and ethnic equality in England, based on comparisons and parallels among a large number of public institutions in their attitude towards ethnic minorities. His studies found a surprising similarity between the police force and universities in their preference for whites and their discrimination against blacks and other ethnic minorities. Yolanda Niemann (Flores-Niemann, 1999) claims that only 6\% of the professors in the United States are members of ethnic minorities.

Studies on the contribution of higher education to minorities do not present a clear picture. According to some of them, minorities attribute importance to higher education in order to escape a fate of unemployment and social marginality (Hagel \& Shaw, 1996). Higher education bridges gaps between the majority and the minority, empowers the minority and equips those who study with more opportunities to organize in order to improve the economic, educational and political situation (Astin, 1982).

Minorities tend to view higher education as an important factor in their struggle for social and political rights (Iannell, 2007; McCluskey, 2015) and as a means of improving their access to economic resources. But the ability of academia to bridge gaps and empower minorities also depends on factors such as the openness of the socioeconomic system, the type of regime, the quality of the democracy, and, of course, the relationship between the minority and the majority in the country.

Higher education enables the acquisition of five types of resources: professional resources, self-fulfillment and broadening horizons, social resources (an opportunity to make contacts and to meet with similar and 
different people), affiliations depending on religion and gender, and community resources, which are considered vital for students (Oplatka \& Hertz-Lazarowitz, 2009).

Studies have shown that the commitment of the Afro-American minority to higher education is greater than that of the majority group, because it is seen as a primary tool for social mobility (Basit, 1997).

In the United States, research has dealt with racial representation (Altbach, 1990). Some places adopted a policy of affirmative action in accepting African-Americans into institutions of higher learning; however, they are still under-represented in the prestigious universities.

In light of data, which indicate that the gaps in education in the United States are widening, ending affirmative action for minorities in university acceptance is under increasing debated. Of 43,000 doctorates awarded by universities since 1994, only $2.1 \%$ went to Hispanics and $0.3 \%$ to African-Americans. This is in a country where Afro-Americans have made great strides in terms of representation in the government, and where they are not encumbered by a different minority language or a national conflict (Rubinstein, 2003).

Modood and Shiner (1994), who studied the representation of minorities in higher education in England, found that there has been a significant increase in the percentage of young people from minority ethnic groups in institutions of higher education (Modood \& Shiner, 1994), but in England and in the United States there is still a clear under-representation of Bangladeshi, Pakistani, African-American and Hispanic students. In addition, even when blacks, Muslims and Hispanics do attend institutions of higher learning, they are mostly accepted into non-prestigious academic institutions (like the newer universities in England).

Many researchers have tried to find the reasons for the under-representation of minorities in academic institutions. Oplatka and Hertz-Lazarowitz (2009) found a variety of causes in the research literature and emphasized some of them. Modood and Shiner pointed to the tendency of ethnic minorities to choose prestigious professions, into which it is hard to be accepted and which are not always in geographical proximity; Richards (1996) emphasized the biases of the dominant groups against certain groups in acceptance interviews; another study blamed financial restrictions (Metcalf, Rolfe, Stevens, \& Weale, 2005). Kettley (2007) focused on low achievements in the schools and mistaken ideas regarding the role of the university in society. Still others examined the factors influencing the representation of female minority members in academia. Kettley emphasized the absence of family support and low aspirations; David (2007) explained that the accessibility of academia to additional sectors does not necessarily guarantee them social equality and acceptance.

\section{Higher Education Among the Arab Citizens of Israel}

In Israel, the government is directly responsible for the education of most Israeli schoolchildren. The Israeli government operates two separate school systems for more than 1.8 million schoolchildren: A Jewish system and an Arab system. The Arab system, constituting nearly one quarter of this number. Under international law, states may offer children separate educational systems for linguistic or religious reasons, but they may not discriminate while doing so (Coursen-Neff, 2003). However, Arab education in Israel receives inferior provisions for training, supervision, as well as for nature and art lessons. In general, the physical conditions in the schools are bad and they lack basic study aids. The Arab schools have significantly fewer of the unique programs in which the Ministry of Education invests. However, discrimination in budgets and "how many” questions cannot lead to an understanding of the whole picture of inequality (Golan-Agnon, 2006). Furthermore, a recent OECD report on the labor market in Israel shows that Arab students receive inadequate education in terms of core subjects (Mossawa, 2013). 
Access to higher education began to expand already in the 1970s and the 1980s, but the real change that made education accessible to all sectors of the Israeli population began only in the 1990s. A large number of academic colleges were established in Israel and at the same time, universities opened their doors to residents of the periphery and the disadvantaged. Within a decade, and especially from 1982-1993, the number of students in universities increased by $50 \%$, and in colleges by $700 \%$. As a result, the percentage of Arab students in universities increased from $2.9 \%$ in the 1970 s to $6.7 \%$ in the mid-1980s (Arar, 2012; A'li, 2013; Haj-yehia \& Arar, 2014; Arar \& Haj-yehia, 2016).

The constant increase in the number of Arab students in Israel demonstrates that their low numbers prior to the increase was not due to cultural factors, but to the obstacles placed before them by educational institutions, the neglect in elementary and high school education, and the structural barriers they face. These barriers are evident in an examination of the percentage accepted into universities relative to their numbers according to age group: In the mid-1980s, Arabs were $22.7 \%$ of 18 -year-olds, but only $7.4 \%$ of them were accepted to universities (A'li, 2010; 2013; Scope, 2015²).

Two main barriers block the path of Arabs who want to acquire a higher education: The first is the failure to receive a complete and high-quality matriculation certificate, which meets the minimum requirements of the universities, and the second is the failure to begin higher education during the first two years after high school (A'li, 2013).

In an interview in June 2011 in Haaretz (Haaretz, June 28, 2011) Prof. Majid Al-Haj, a former member of the CHE and former vice president and dean of research of the University of Haifa, said that the Arab student faces several barriers: The psychometric exam, which is not culturally adapted to Arab examinees, and the teaching methods in the Arab schools, which are based on accumulating information in order to regurgitate it during the exam, without any development of critical, creative, or logical thinking. Regarding the barriers in the universities themselves, Al-Haj said: “Today the Arab student spends the first two years dealing with the basic problems of his absorption in the university. There is no serious attention to the Arab student on the part of the universities and the colleges; another thing we discussed in the committee is the cultural atmosphere in the university, which leads to alienation in the Arab student because it is not based on a multicultural concept" (Ibid, 2011).

However, in recent years, there has been a significant improvement in the percentages of eligibility for matriculation certificates, and as a result, the percentage of those accepted to institutions of higher education in the two years following high school has increased from 10.7\% in 1991 to $19.2 \%$ in 2001. Al-Haj believes that there are two reasons for this: (1) collective motivation, namely the desire of Arab intellectuals to contribute to raising the community's standard of living and to work for social and economic prosperity, and (2) individual motivation, namely a desire for personal advancement, a career and social status. The community of Arab academics in Israel feels a responsibility and is on a mission to advance their civil, economic, and political status in the face of the problems and challenges within the community (Al-Haj, 1996; A'li, 2013).

Mustafa (2007) notes three factors, which have influenced the acquisition of higher education among Palestinian Arabs in Israel. The first was the 1948 war, which led to the destruction of the urban cultural centers of Palestinian society.

\footnotetext{
${ }^{2}$ Retrieved from http://www.haaretz.co.il/news/education/.premium-1.2739165.
} 
The British Mandate enabled the Jewish community to establish the Hebrew University of Jerusalem and the Technion in Haifa in the mid-1920s, but did not allow the Arabs to establish a Palestinian university or even an Arab-Jewish university.

The second cause was the situation in the Israeli academic world. Higher education among Arab citizens was gained in Israeli universities, which were engaged in constructing the Zionist historical narrative and shaped an Israeli sociology, which studied the development of the Arab minority in Israel in a distorted manner. The State of Israel has not allowed the Arab minority to establish an Arab university to this day. The Israeli government is preventing the establishment of an Arab university because it is afraid that it will turn into an arena of nationalist activity, and in any case, the Israeli establishment refuses to approve autonomous independent institutions for Arabs.

No university exists in Israel using the Arabic language for instruction. This may not seem to be particularly insidious, but the lack of a university providing instruction in Arabic ensures disproportionate benefit to Jewish students by educational funding from the U.S. and EU (Mossawa, 2013).

In December 2012 there was a cornerstone laying ceremony for an academic campus in the city of Nazareth, which is considered a first step on the way to building an Arab university institution ${ }^{3}$. The former Education Minister Gideon Sa'ar opposed the initiative, claiming that such a university would undermine the integration of the Arabs into the country (Nassar, 2013) ${ }^{4}$.

The third factor that has affected the acquisition of higher education by Arab citizens is their structural exclusion in all areas of life, and especially from places of work and centers of political influence. In Israel, education is only one of several areas in which Arab citizens face discrimination. Indeed, there is no general prohibition of discrimination or guarantee of equality in any of Israel's Basic Laws. Indeed, equality was explicitly excluded from the Basic Law (Coursen-Neff, 2003).

The Israeli-Arabs path to higher education is a kind of obstacle course consisting of learning challenges, social and cultural challenges, and systemic institutional challenges (Taha \& Zawawi, 2015). Challenges include a lack of interest in studies, difficulties in acceptance into institutions of higher learning and in completing a degree, and barriers to finding employment, which is commensurate with their education. Each barrier is influenced by the preceding one, but often many obstacles appear at the same time and make it difficult to cope (Ibid, 2013).

\section{The Study}

\section{Methodology}

The question of the representation of Arab citizens on university faculties in Israel and the patterns of discrimination in hiring and absorption into institutions of higher education has been virtually ignored in research, despite its importance to the Arabs in Israel. Most of the research on the subject relies on committee reports, press releases, civil society reports and short reports from the CHE.

As mentioned, this study wishes to examine the representation of Arab citizens in Israeli universities. For the purpose of the study, we used a combination of qualitative and quantitative methods: A questionnaire,

\footnotetext{
${ }^{3}$ There is no Arab university in Nazareth and it's wrong to establish a sectoral university, Alakhbar, January $18,2013$. www@barnet.co.il.

${ }^{4}$ Ibid.
} 
in-depth interviews, and a textual analysis in order to take advantage of both methods and to minimize their weaknesses as far as possible.

The questionnaire, which was sent to university heads was composed of 32 questions designed to attain specific information regarding the goals of the study, and most of the findings were based on this information. After it was formulated, the questionnaire was validated with the help of experts in the field in order to ensure that the questions align with the objectives of the study.

After the questionnaire was approved by the members of the steering committee and successfully passed a pilot study, it was sent to the target population, which included the heads of the research universities (seven universities and the Open University) and the heads of two colleges (the Western Galilee College and Kaye Academic College of Education). One of the colleges did not respond. The study findings are valid for the academic year 2013-2014.

\section{Findings}

Five of the university representative (presidents or recors) from the University of Haifa, the Technion, the Open University, Ben-Gurion University and the Hebrew University (or someone else on their behalf) responded to our request, filled out the entire questionnaire, or answered in writing regarding all the research issues they were asked to discuss. Tel-Aviv University provided most of the information relating to the research questionnaire, but Bar-Ilan University provided partial information which we proceeded to complete with in-depth interviews and informal conversations with faculty members and those in other positions, or from the university website. These two universities claimed that they did not have information about the ethnic origins of the students and employees.

The Weizmann Institute adamantly refused to cooperate with the study, using the same argument. The information about the Weizmann Institute was therefore gathered from informal sources and from the institute's website. The heads of the Western Galilee Academic College provided full information about all the research questions. The Kaye Academic College of Education in the Negev did not respond to our request, despite reminders and phone conversations with institution officials.

The response rate to the research questionnaire was very high: $62.5 \%$ full response; $25 \%$ partial response; and $12.5 \%$ failure to respond. In previous Sikkuy studies from 1999 and 2007, the response rate of university heads was below 20\% (Awad, 2008). The findings presented below were provided by university heads, and reflected the representation of Arab citizens in the seven research universities in Israel in the three areas of the study: Arab students in the universities; Arabs on the faculty ${ }^{5}$ and Arabs in the administration. Some of the findings presented below differ somewhat from the analyses of the central bureau of statistics or the CHE because their data is based on estimates or information that the universities sent directly to them or the Knesset committees. Some of the information was partial and most was unverified.

The study did not rely on this data alone, but was based on the data from the universities, which were later verified and cross-referenced in the field. We also interviewed senior faculty members, advisers to university heads on Arab student affairs ${ }^{6}$, members of the student associations, employees of the dean of students and others.

\footnotetext{
${ }^{5}$ A member of the faculty for the purpose of the study is a full professor, an associate professor, a senior lecturer or a lecturer (with tenure).

${ }^{6}$ A new position held by one of the senior faculty members.
} 


\section{Students}

In 2011-2012 a total of around 298,400 students were studying for an academic degree in all the institutions of higher education in Israel. Of these, 258,700 students in the universities, the academic colleges and the teacher training colleges, and the rest in institutions that grant a degree but are not among the three types of above-mentioned institutions. Some $75 \%(194,100)$ were studying for a BA $(58,100$ of them new students), $20.4 \%(52,700)$ for an MA, $4.1 \%$ (about 10,600) for a doctorate, and the rest for a certificate. In the 2011-2012 academic year, about 155,800 students studied in research universities, for all types of degrees. Of these, 14,895 were Arabs, 9.6\% of all university students in Israel. This means that the representation of Arab citizens among university students is about half of their representation in the general population, and far less than their representation in the relevant age group. It should be noted that this study deals with students in Israel, and does not take into account those studying in Jordan (whose numbers are estimated in the thousands), Europe (several hundred) and the rest of the world (several hundred).

Table 1

Distribution of Arab and Jewish Students by Degree and Academic Institution 2011-2012

\begin{tabular}{|c|c|c|c|c|c|c|c|c|}
\hline $\begin{array}{l}\text { Students/ } \\
\text { Institution }\end{array}$ & BA Jews & Arabs & MA Jews & Arabs & Ph.D. Jews & Arabs & Total Jews & Total Arabs \\
\hline \multirow{2}{*}{ University of Haifa } & 6,164 & 2,679 & 5,538 & 1,360 & 968 & 152 & 12,670 & 4,191 \\
\hline & $69.7 \%$ & $30.3 \%$ & $80.3 \%$ & $19.7 \%$ & $86.5 \%$ & $13.5 \%$ & $75.1 \%$ & $24.9 \%$ \\
\hline \multirow{2}{*}{$\begin{array}{l}\text { Technion-institute of } \\
\text { Technology }\end{array}$} & 6,943 & 1,550 & 2,157 & 78 & 887 & 33 & 9,987 & 1,661 \\
\hline & $81.75 \%$ & $18.25 \%$ & $96.5 \%$ & $3.5 \%$ & $96.5 \%$ & $3.6 \%$ & $85.7 \%$ & $14.3 \%$ \\
\hline \multirow{2}{*}{ Tel Aviv University } & 14,599 & 1,613 & 10,129 & 489 & 2,148 & 58 & 26,876 & 2,160 \\
\hline & $90.1 \%$ & $9.9 \%$ & $95.4 \%$ & $4.6 \%$ & $97.4 \%$ & $2.6 \%$ & $92.6 \%$ & $7.4 \%$ \\
\hline \multirow{2}{*}{ Bar-Ilan University } & 17,079 & 378 & 6,000 & 12,594 & 1,921 & 22 & 25,000 & 525 \\
\hline & $97.8 \%$ & $2.2 \%$ & $98 \%$ & $2 \%$ & $98.9 \%$ & $1.1 \%$ & $98 \%$ & $2 \%$ \\
\hline \multirow{2}{*}{ Ben-Gurion University } & 13,440 & 508 & 4,700 & 181 & 1,400 & 37 & 19,540 & 726 \\
\hline & $96.4 \%$ & $3.6 \%$ & $96.3 \%$ & $3.7 \%$ & $97.4 \%$ & $2.6 \%$ & $96.4 \%$ & $3.6 \%$ \\
\hline \multirow{2}{*}{ Hebrew University } & 11,500 & 1,321 & 6,800 & 216 & 2,700 & 95 & 21,000 & 1,632 \\
\hline & $89.7 \%$ & $10.3 \%$ & $97 \%$ & $3 \%$ & $96.6 \%$ & $3.4 \%$ & $92.8 \%$ & $7.2 \%$ \\
\hline \multirow{2}{*}{ Open University } & 34,809 & 3,518 & 3,481 & 235 & & & 41,720 & 3,753 \\
\hline & $91.6 \%$ & $8.4 \%$ & $93.7 \%$ & $6.4 \%$ & & & $91.7 \%$ & $8.3 \%$ \\
\hline \multirow{2}{*}{ Total } & 104,534 & 11,567 & 38,805 & 2,684 & 10,024 & 397 & 156,793 & 14,645 \\
\hline & $90.4 \%$ & $9.6 \%$ & $93.6 \%$ & $6.4 \%$ & $96.2 \%$ & $3.8 \%$ & $91.5 \%$ & $8.5 \%$ \\
\hline
\end{tabular}

The increase in the percentage of Arab students in recent years is more significant in colleges than in universities. The CBS data from 2011 indicate that 12\% of BA students are Arabs. The percentage who study for a BA in college and go on for advanced degrees is very small.

The highest number of Arab students is found in the University of Haifa, where they constitute about $25 \%$ of all the students. The lowest percentage is in Bar-Ilan University (not including the colleges operating under its aegis, some of which have a relatively high percentage of Arabs. The percentage of Arab students in the Safed Academic College, for example, is almost 60\%, and in the Western Galilee Academic College about 40\%. In the academic year 2015-2016, the percentage of Arab students in the Safed Academic College rose to 67\% and in the Western Galilee Academic College to about 50\%).

\section{Faculty}

According to the Israeli Central Bureau of Statistics data, in recent years there has been a decline in the number of members of the senior faculty or those with permanent jobs in Israeli universities. In 1999-2000,

\footnotetext{
${ }^{7}$ The figures do not include students in pre-academic preparatory institutions and foreign students.
} 
there were 4,684 faculty members, and since then the decline in the number of positions has continued until it reached 4,326 in the 2009-2010 academic year, a drop of about 7.6\% in a decade.

The findings of our study indicate that the trend of decline has slowed, and since the 2009-2010 academic year, 257 new senior faculty members have joined the academy. One explanation is the government's decision of November 2010 to begin a multi-year project to try to bring Jewish-Israeli scientists back from abroad.

The findings of the study indicate that in the 2013 academic year 4,665 senior lecturers taught in Israeli universities, 4,583 Jews and 82 Arabs (1.75\%), lower than the CHE estimate regarding the percentage of Arab lecturers (2.7\%). In comparison with data from previous years, we find that in 1999 there were 64 Arab lecturers, constituting $1 \%$ of the senior faculty in research universities, while in the 2006-2007 academic year their representation increased to $1.4 \%$. From 1999-2000 to date, 18 Arab lecturers have joined the senior faculty, an increase of $0.25 \%$ compared to 1999-2000. This means that from 1999 to 2012 the number of Arabs on university faculties increased at a rate of $0.02 \%$ annually.

Table 2

Distribution of Faculty Members (Arabs and Jews) by Academic Institution

\begin{tabular}{llll}
\hline Faculty/Institution & Jews (\%) & Arabs (\%) & Total \\
\hline University of Haifa & $569(96.1 \%)$ & $23(3.9 \%)$ & $592(100 \%)$ \\
Technion & $552(98.75 \%)$ & $7(1.25 \%)$ & $559(100 \%)$ \\
Tel-Aviv University & $923(98.5 \%)$ & $14(1.5 \%)$ & $937(100 \%)$ \\
Bar-Ilan University & $660(99.7 \%)$ & $2(0.3 \%)$ & $662(100 \%)$ \\
Ben Gurion University & $800(97 \%)$ & $25(3.0 \%)$ & $825(100 \%)$ \\
Hebrew University & $1,000(99.1 \%)$ & $10(0.99 \%)$ & $1,010(100 \%)$ \\
Open University & $79(98.75 \%)$ & $1(1.25 \%)$ & $80(100 \%)$ \\
Total & 4,583 & 82 & 4,665 \\
& $(98.25 \%)$ & $(1.75 \%)$ & $(100 \%)$ \\
\hline
\end{tabular}

As shown in Table 2, the University of Haifa and Ben Gurion University had the largest number of Arab faculty members; however,the number is not high. Bar-Ilan University and the Hebrew University had the lowest percentage (less than 1\%). In other universities, the percentage of Arab lecturers also remains marginal (1.25-1.5\%).

The study also examined the percentage of Arab deans, faculty heads and rectors in universities. Of the 67 deans, there was one Arab in 2011 (Prof. Majid Al-Haj, dean of research at the University of Haifa) who has concluded his term, and today there is not a single Arab dean in any Israeli research university. The same is true of faculty heads and rectors. There are however a few faculty members who have served and are serving as department heads in universities in recent years.

\section{Administrative Staff}

The members of the administration in the universities are particularly important because due to their frequent contact with the student body and the fact that they mediate between students and the faculty and university authorities. Fair representation of Arab citizens on the administrative staff should make things easier for Arab students, reduce their sense of foreignness and alienation, and open new employment opportunities for students and graduates.

The findings of the study indicate that Arabs hold very few administrative positions. Their numbers are even lower than that of Arab faculty. 
Table 3

Distribution of Members of the Administrative Staff (Jews and Arabs) by Academic Institution

\begin{tabular}{llll}
\hline & Jews (\%) & Arabs (\%) & Total \\
\hline Haifa & $751(97 \%)$ & $24(3 \%)$ & $775(100 \%)$ \\
Technion & $1,458(99.2 \%)$ & $12(0.8 \%)$ & $1,470(100 \%)$ \\
Tel Aviv & $1,450(99.4 \%)$ & $9(0.6 \%)$ & $1,459(100 \%)$ \\
Bar-Ilan & $1,000(99.9 \%)$ & $1(0.1 \%)$ & $1,001(100 \%)$ \\
Ben-Gurion & $1,355(99.8 \%)$ & $3(0.2 \%)$ & $1,358(100 \%)$ \\
Hebrew University & $1,200(99.9 \%)$ & $1(0.8 \%)$ & $1,201(100 \%)$ \\
Open University & $855(97.5 \%)$ & $22(2.5 \%)$ & $877(100 \%)$ \\
Total & $8,069(99.1 \%)$ & $72(0.9 \%)$ & $8,141(100 \%)$ \\
\hline
\end{tabular}

Of over 8,141 members on the administration staff in the universities, only 72 are Arabs (0.9\%). Among administrative assistants to department heads or faculty coordinators, there is not a single Arab.

The CBS and CHE figures, as reported in the media, stated that in 2006-2007 there were 8,558 administrative employees in the universities, 23 of them Arabs ( $0.26 \%$ of the total). The same sources stated that in 2011, about $1.6 \%$ of all administrative employees were Arabs. As mentioned, these figures are far higher than the findings of our study. The differences probably stem from a difference in the definition of the administrative staff. We will once again emphasize that our figures were obtained from the universities themselves.

In summary, the representation of Arab citizens in institutions of higher education in Israel constitutes the following numbers:

- The percent of Arab students in Israeli universities is 9.6\%.

- The percent of Arab faculty members in Israeli universities is 1.75\% (Scope, 2015).

- The percent of Arab administrative staff in Israeli universities is $0.9 \%$.

\section{Conclusion}

For scholars of social stratification, the key question about educational development is whether it reduces inequality by providing more opportunities for persons from disadvantaged strata, or magnifies inequality by expanding opportunities disproportionately for those who are already privileged. The development of higher education and its relation to social stratification deserves special scrutiny (Arum, Gamoran, \& Shavit, 2007). In regards to our study, the winners seem to be those who are already privileged: The dominant ethno-national group. This study is a product of discussions, research and the compilation of data over a period of 18 months. The importance of higher education and the right to it is one of the only issues receiving a broad consensus in Israeli society, but since the establishment of the state most of the resources have been channeled towards Jews. In the past decades, we are witness to an increase in the number of Arab students in Israeli institutions of higher learning, but this increase has not been transferred into significant participation of Arab intellectuals and academics in the higher education system, as policy makers or as holders of senior leadership positions in academic institutions.

It is our hope that this study will contribute to shedding light on the subject of Arab representation in academia and will encourage a meaningful and in-depth public discourse on the issue.

${ }^{8}$ Partial data was published by Scope (2015) http://www.haaretz.co.il/news/education/.premium-1.2739165. 
Arab students will constitute an integral and important part of the cultural, economic and political elite in Israel in the coming decades. Increasing their percentage in the academic system will only reinforce the strength of Israeli society in general, and will contribute to an improvement in the complex and problematic relations between Jewish and Arabsin Israeli society. In order for these elite to be able to progress in the future, there is a need for a policy of immediate absorption and integration into the system today. Employment of Arab academics, both as lecturers and as administrative workers, including their appointment to boards of directors, is essential. We need to continue to monitor and report on the absorption and employment of Arab citizens in the higher education system in the coming years.

The research findings indicate a very gloomy picture for Arabs in the higher education system. Arabs constitute fewer than $10 \%$ of students in all programs, while the percentage of lecturers, members of the administrative staff and directors is no more than $2 \%$ at best. In some of the universities, Arab representation in some of the categories we examined is zero!

It is very important to clarify that within the Arab society in Israel, there are more than 538 people holding Ph.D degrees, or higher and more than 400 Ph.D. candidates. The study findings show that 82 of them are faculty members in Israeli Universities. Others are teaching in secondary schools, post-secondary institutions, and teachers' training colleges. A few of them are teaching in colleges without tenure or teaching at Palestinian universities in the Palestinian Authority. A majority of them believes that they are working in institutions that do not match their skills and competencies. They feel that their potential is wasted; they are frustrated and part of them feel that they are not academically employed.

There is scarce research focusing on unemployed scholars holding postgraduate degrees (Hlahla, 2008). The research which has already been done, demonstrates a tendency towards their becoming more and more radical in their views and attitudes. Future research should perhaps set out to examine social and political attitudes among such unemployed scholars.

For scholars of social stratification, the key question about educational advancement is whether it reduces inequality by providing more opportunities for persons from disadvantaged strata, or increases inequality by disproportionately expanding opportunities for those who are already privileged. The development of higher education and its relation to social stratification deserves special scrutiny (Arum et al., 2007). Our study demonstrates that the winners are those who are already privileged, the dominant ethno-national group.

This situation requires the Council for Higher Education, university administrations, and the relevant government institutions, to act immediately and effectively to include Arab lecturers in the faculty of institutions of higher education. In addition, we must act to include Arab representatives in their internal institutions and to end the policy of virtually total exclusion of Arabs from these institutions.

\section{References}

A'li, N. (2010). Attitudes toward bilingual Arabic-Hebrew education among students at the University of Haifa, Israel. Journal of Greater Middle Eastern studies, 3(1), 103-144.

A'li, N. (2011). Task allocation between ideology and actual behavior in transition societies: The case of the Palestinian family in Israel. Journal of Greater Middle Eastern studies, 4(1), 1-45.

A'li, N. (2013). Representation of Arab citizens in the Institutions of Higher Education in Israel. Sikkuy: Jerusalem and Haifa. Abu-Asba, K. (1997). The Arab education system in Israel: Present situation and possible organization alternatives. Givat Haviva: Institute for Peace Studies. 
Abu-Asba, K. (2005). The learning achievements of female Arab students in Israel as a factor in their entry into the employment market and as an opportunity for changing their social status. In A. Paldi (Ed.), Education in the test of time 2 (pp. 627-646). Tel Aviv: Histadrut Hamorim Publication.

Al-Haj, M. (1996). Higher education among Arabs in Israel: Control and social change. Jerusalem: Magnes Publishers and the Floersheimer Institute for Policy Studies.

Altbach, P. (1990). The racial dilemma in American Higher Education. Journal for Higher Education Management, 5(2), 3-16.

Arar, K. (2012). Access to higher education among the Arabs in Israel. Or Yehuda: The Center for Academic Studies.

Arar, K., \& Haj-Yehia, K. (2016). Higher Education and the Palestinian Arab Minority in Israel. Palgrave Macmillan.

Arum, R., Gamoran, A., \& Shavit, Y. (2007). More inclusion than diversion: Expansion, differentiation, and market structure in higher education. Stanford, California: Stanford University Press.

Astin, A. (1982). Minorities in higher education. San Francisco: Jossey-Bass.

Awad, Y. (2008). Fair representation of Arabs in the higher education system in Israel. Sikkuy: Position Paper.

Basit, T. (1997). Eastern values, Western milieu: Identities and aspiration of adolescent British Muslim girls. Aldershot: Ashgate.

Coursen-Neff, Z. (2003). Discrimination against Palestinian Arab children in the Israeli education system. NYUJ Int'l. L. \& Pol., 36, 749.

David, M. (2007). Equality and diversity toward a sociology of higher education for the 21st century. British Journal of Education, 28(5), 675-690.

Flores-Niemann, Y. (1999). The making of a token: A case study of stereotype, threat, stigma, racism and tokenism in academy. Journal of Women's Studies, 20(1), 111-134.

Golan-Agnon, D. (2006). Separate but not equal discrimination against Palestinian Arab students in Israel. American Behavioral Scientist, 49(8), 1075-1084.

Hagel, A., \& Shaw, C. (1996). Opportunity and disadvantage. London: Policy Studies Institute.

Haj-Yehia, K., \& Arar, K. (2014). The internationalization of higher education: Studies in the mobility of Arab students from Israel outside the country. Al-yanbua'.

Hlahla, J. (2008). "I am nothing just zero”: Exploring the experiences of black unemployed teachers in a South African rural community (Doctoral dissertation).

Iannelli, C. (2007). Inequalities in entry to higher education: A comparison over time between Scotland and England and Wales. Higher Education Quarterly, 61(3), 306-333.

Jewsona, N., Masona, D., Bowen, R., Mulvaney, K., \& Parmar, S. (1991). Universities and ethnic minorities: The public face. Journal of Ethnic and Migration Studies, 17(2), 183-199.

Kettley, N. (2007). The past, present and future of widening participation research. British Journal of Sociology of Education, 28(3), 333-347.

Klein-Avishai, H. (2012). The higher education system in Israel 2012 on the path to growth. Jerusalem: Council for Higher Education, the Committee for Planning and Budgeting.

Leathwood, C., Uvanney, M., \& Marie-Pierre, M. (2009). The experience of black and ethnic minority staff working in higher education. London: Institute for Policy Studies in Education, Metropolitan University.

McCluskey, N. (2015). Many factors at play in minority access to higher education. Cato Institution.

Meri, S. (1985). Arab education in Israel. Politika, 4, 34-36.

Meri, S. (1986). School and society in the Arab village in Israel. Iyunim Behinukh, 4(6), 85-104.

Metcalf, H., Rolfe, H., Stevens, P., \& Weale, M. (2005). Recruitment and retention of academic staff in higher education. National Institute of Economic and Social Research.

Modood, T., \& Shiner, M. (1994). Ethnic minorities and higher education: Why are there differential rates of entry? London: Policy Study Institute.

Mossawa Center. (2013). Discrimination against the Arab minority in Israel: The Mossawa center's briefing paper for the US state department human rights report on Israel. Haifa: The Mossawa Center.

Mustafa, M. (2007). Changes in higher education among the Arab minority in Israel. In K. Arar, \& K. Haj-Yehiae (Eds.), Academics and higher education among Arabs in Israel-Issues and dilemmas (pp. 13-46). Tel Aviv: Ramot.

Nassar, F. (2012). The first Arab university in Israel—In Nazareth. Mako/News 2.

Oplatka, I., \& Hertz-Lazarowitz, R. (2009). Women and minorities in Western academia. In R. Hertz-Lazarowitz, \& I. Oplatka (Eds.), Gender and ethnicity in higher education in Israel. Haifa: Pardes Publishers.

Pilkington, A. (2011). Institutional Racism in the Academy: A case study. Trentham Books. 
Pullias, E. (1964). Higher education in modern society. Journal of Improving College and University Teaching (vol. 12).

Richards, P. (1996). The classroom of despair: A black professor at a white college. Journal of Blacks in Higher Education, 10(1), 1-44.

Rubinstein, A. (2003). Ethnic gaps in education. Retrieved from http:// amnonrubinstein.com

Shafferman, K. (2007). Inequality in higher education in Israel. Parliament 54. Jerusalem: The Israeli Institute for Democracy.

Taha, M., \& Zawawi, N. (2015). The Palestinian Community in the Israeli-Academia: The effect of the Zionist ideology. Um Al Fahem: Center for Contemporary Studies. 